\title{
Meraih Surga dengan Sabar dan Syukur
}

\author{
Muhammad Arsyam \\ Sekolah Tinggi Agama Islam Darud Dakwah wal Irsyad (STAI DDI) Kota Makassar \\ Email: arsyam0505@gmail.com \\ Ibnu Hajar Sainuddin \\ Sekolah Tinggi Agama Islam Darud Dakwah wal Irsyad (STAI DDI) Kota Makassar \\ Email: dewaibnuhajar@gmail.com
}

\begin{abstract}
Abstrak
Salah satu menjadi tujuan manusia setelah di hari mkemudian adalah surga. Untuk menggapai surga yang diinginkan, maka ada jalan yang harus ditemput sebagai syarat untuk mendapatkannya.. Dalam kehidupan ini, sabar dan syukur merupakan dua indikator sebagai ciri orang yang beriman. Sabar dan syukur menjadi salah satu cara untuk meraih surga tersebut.
\end{abstract}

Kata Kunci: Surga; Sabar; Syukur.

\section{Pendahuluan}

Segala puji bagi Allah Subhanahu wa Ta'ala yang telah memberikan kenikmatan yang tak terhingga untuk kita semua, semenjak kita lahir sampai saat sekarang ini nikmat Allah tidak ada henti-hentinya Dia berikan kepada kita.

Di antara nikmat Allah yang paling besar yang harus kita syukuri adalah nikmat Islam dan iman. Keislaman dan keimanan adalah sebesar-besarnya jalan yang mengantarkan seseorang berbahagia hidup di dunia terlebih lagi di akhirat. Berbeda dengan orang-orang kafir, orang yang ingkar kepada Allah Subhanahu wa Ta'ala dan Rasul-Nyashallallahu 'alaihi wa sallam, mereka terancam dengan kekal diadzab di neraka. Rasulullah shallallahu 'alaihi wa sallam bersabda,

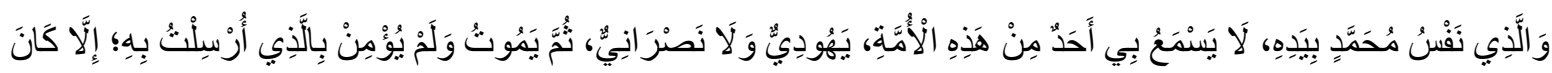

$$
\begin{aligned}
& \text { مِنْ أَصْحَابِ النَّارِ }
\end{aligned}
$$

Artinya:

"Demi Allah, tidaklah seorang pun dari umat ini, entah itu Yahudi atau Nasrani, yang mendengar tentang diriku, lalu ia mati dalam keadaan belum beriman dengan risalahku, melainkan ia akan menjadi penghuni neraka." (HR. Muslim)

Oleh karena itu kita ucapkan puji dan syukur kepada Allah yang telah melahirkan kita dari orang tua yang muslim, sehingga kita pun menjadi seorang muslim dan tumbuh di lingkungan orang-orang Islam. Hal yang tidak dinikmati oleh bayi-bayi yang lahir dari orang-orang kafir sehingga mereka tumbuh menjadi orang ingkar kepada Allah dan Rasul-Nya.

Kemudian shalawat serta salam semoga senantiasa tercurah kepada Nabi kita Muhammad shallallahu 'alaihi wa sallam, keluarga, sahabat, serta pengikut beliau hingga akhir zaman.

\section{Pembahasan}

Kehidupan ini tidak terlepas dari cobaan dan ujian. Tidak ada seorang pun yang terlahir ke dunia tanpa mengalami ujian sedikit pun (Fauzi, 2018). Seseorang yang kaya dan berharta, ia Allah 
uji dengan kekayaannya, apakah ia bersyukur atau malah kufur (Masyhuri, 2013). Seseorang yang hidup dalam keadaan kurang, maka tidak diragukan lagi ini adalah cobaan kehidupan (Syawie, 2011). Allah uji orang tersebut apakah ia bersabar atau malah menempuh cara-cara yang Allah haramkan demi terbebas dari kemiskinan.

Bagi yang bersedih mencela takdir karena kehilangan anggota keluarganya. Beliau kehilangan ayah beliau ketika di dalam kandungan ibunya, ditinggal wafat ibunya ketika beliau berusia 6 tahun, kemudian kakek dan pamannya pun wafat meninggalkan beliau (Mahmuda, 2018). Beliau juga ditinggal wafat dua orang istri beliau di masa hidupnya, beliau menyaksikan anak-anaknya wafat terlebih dahulu meninggalkan beliau, namun beliau adalah hamba Allah yang bersabar.

Namun terkadang karena kelemahan iman, sering mendengar ada orang-orang yang mengatakan "Ah, beliau kan Nabi dan Rasul Allah yang dibimbing oleh wahyu, jadi wajar beliau bersabar (Indrawan, 2013).” Kalimat ini hakikatnya tidak patut diucapkan bagi orang-orang yang beriman kepada beliau. Buktinya ada orang-orang yang shalih yang mereka bukan Rasul dan bukan pula Nabi, namun mereka bersabar ketika ditimpa musibah.

Pada pembahasan kali ini, kita akan membahas sebuah kisah seseorang yang memenuhi hidupnya dengan kesabaran ketika ditimpa musibah dan bersyukur di saat lapang. Cerita ini dikisahkan oleh Abdullah bin Muhammad dan diriwayatkan oleh Imam Ibnu Majah dalam Kitab ats-Tsiqat. Abdullah bin Muhammad menuturkan:

Suatu hari ketika aku menjaga di daerah perbatasan Aris di wilayah Mesir, aku melihat sebuah kemah yang sempit di padang pasir yang terik. Lalu aku pun mendekati kemah tersebut. Aku melihat ada seorang laki-laki yang kedua tangannya buntung, kedua kakinya pun tiada, ditambah telinga yang sudah tuli dan mata yang telah rabun. Namun aku mendengar ia mengatakan

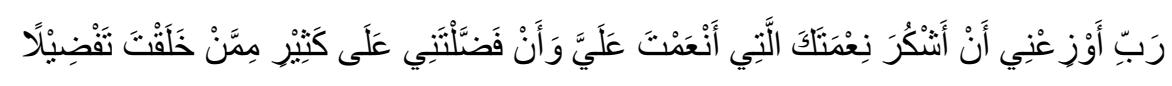

Terjemahnya:

"Ya Tuhanku, tunjukilah aku untuk mensyukuri nikmat yang telah Engkau berikan kepadaku danbersyukur atas kemuliaan yang Engkau berikan kepadaku atas hambahamba-Mu yang lain."

Maka aku pun heran dengan apa yang ia katakan. Lalu aku mendekatinya dan aku tanyakan "Wahai saudaraku atas nikmat Allah yang mana engkau bersyukur?" Ia mengatakan, "Diamlah! Kalau sekiranya Allah datangkan lautan niscaya laut tersebut akan menenggelamkanku, atau ia datang api yang menggunung tentulah api tersebut akan membakar tubuhku, atau ia jatuhkan langit pastilah langit itu menghancurkanku. Tapi aku akan senantiasa bersyukur kepada-Nya." Aku katakana, "Bersyukur atas apa?" Ia menjawab "Dia telah menganugerhkanku lisan, yang senantiasa mengingat dan bersyukur kepada-Nya."

Lalu ia melanjutkan, "Saudaraku, aku memiliki seorang anak yang biasa menyuapiku ketika akhu hendak makan dan mengantarkan aku untuk beribadah (Muhammad, K., Duski, S., \& Ilman, N. 2019).. Namun tiga hari ini aku kehilangannya. Tolong carikan ia untukku.” Aku pun 
mencarikan anaknya, ternyata sang anak diterkam oleh hewan buas. Aku merasa bingung, kalimat apa yang akan aku sampaikan sementara keadaannya sekarang saja sangat memprihatinkan.

Lalu aku datang kepadanya, aku buka cerita dengan mengisahkan kisah Nabi Ayyub. Aku katakana, "Wahai saudaraku tahukah engkau tentang Ayyub?" "Iya aku mengetahuinya." Jawabnya. "Bukankah Allah telah menjadikannya miskin, lalu bagaimana keadaannya?" kataku. Ia menjawab, "Ia bersabdar." Allah pun mewafatkan anak-anaknya, bagaimana keadannya?" Sambungku. "Ia bersabar." Jawabnya. Lalu Allah pun menambah musibahnya dengan penyakit di tubuhnya, bagaimana keadaannya? Tanyaku lagi. "Ia bersabar." Lalu ia memotong, "Saudaraku, katakana dimana anakku! Aku sangat lapar." Aku katakana, "Berharaplah pahala dari Allah atas musibah yang menimpamu, anakmu dimangsa hewan buas.” Lalu ia mengucapkan, “Alhamdullah, segala puji bagi Allah yang telah menganugerahkanku keturunan yang tidak bermaksiat kepadaNya sehingga ia tidak diadzab di neraka." Lalu ia tersendak dan wafat.

Melihat keadaan demikian, aku pun sempat merasakan kebingungan. Bagaimana harus memandikan, mengafani, dan menguburkannya seorang diri. Tak lama setelah itu, datanglah empat orang penunggang kuda menghampiriku. Mereka bertanya, "Wahai saudara, apa yang menimpamu?" Aku menjawab, “Aku bersama seseorang dan ia telah wafat.” Lalu mereka meminta jasad yang telah kututupi itu dibukakan wajahnya, bisa jadi mereka mengenal jasad tersebut.

Sontak ketika melihat wajah jenazah tersebut mereka berteriak "Subhanallah!! Ini adalah mata yang senantiasa menangis karena Allah, wajah yang tertunduk karena takut kepada Allah, dan tangan yang senantiasa digunakan berdoa kepada Allah." Aku pun bertanya, "Wahai saudaraku, apakah kalian mengenalnya?" Mereka menjawab, "Engkau tidak mengenalnya?! Ia adalah Abu Qilabah sahabat dari Abdullah bin Abbas (sepupu Nabi shallallahu 'alaihi wa sallam). Ia menghindar dari jabatan hakim."

Akhirnya kami mandikan, kafankan, dan kami kuburkan ia. Keempat penunggang kuda itu pun melanjutkan perjalanan dan aku kembali berjaga-jaga di daerah perbatasan.

Kisah Abu Qilabah tidak hanya usai sampai disitu saja. Ia adalah seorang yang bersabar dengan musibahnya dan senantiasa bersyukur kepada Allah dengan lisannya. Lalu apa buah dari amala agungnya ini. Abdullah bin Muhammad kembali menuturkan kisahnya:

Di malam hari aku pun bermimpi di tengah lelapnya tidurku. Aku melihat seorang laki-laki mengenakan sutera hijau yang indah, berjalan dengan penuh wibawa, di sebuah taman (yang dalam mimpiku) surga. Laki-laki itu mengulang-ulang ayat

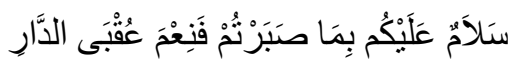

Keselamatan atas kesabaranmu. Maka alangkah baiknya tempat kesudahan itu (QS. Ar-Ra'du: 24)

Aku menghampirinya dan bertanya, "Wahai saudaraku, bukankah Anda adalah orang yang kemarin kami makamkan?" "Iya” Jawabnya. "Apa yang membuatmu mencapai derajat yang mulia ini?” Tanyaku lagi. Ia menjawab, "Sesungguhnya di surga itu ada sebauh derajat, yang tidak akan diperoleh kecuali dengan bersabar ketika ditimpa musibah dan bersyukur di kala lapang."

Demikianlah buah kesabaran, seseorang mencapai derajat yang tinggi lagi mulia di dunia dan akhirat. Bisa jadi di dunia orang yang sabar itu terlihat hina di mata orang lain, namun ia tetap 
mulia di sisi Allah dalam kehidupan dunianya. Jangan sampai kita bersyukur kepada Allah tatkala lapang dan mencela serta protes tatkala ditimpakan kesempitan. Allah Subhanahu wa Ta'ala berfirman,

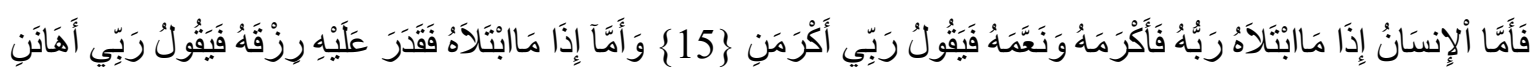

Terjemahnya:

"Adapun manusia apabila Tuhannya mengujinya lalu dia dimuliakan-Nya dan diberi-Nya kesenangan, maka dia akan berkata: "Tuhanku telah memuliakanku. Adapun bila Tuhannya mengujinya lalu membatasi rizkinya maka dia berkata: "Tuhanku menghinakanku." (QS. Al-Fajr: 15-16)

Seperti halnya untuk meraih surga yang membutuhkan sabar, dalam beribadah pun dibutuhkan kesabaran. Ibadah haji atau umrah membutuhkan kesabaran karena ganjarannya adalah surga (Hajar, 2014). Kita memohon kepada Allah Subhanahu wa Ta'ala agar menjadikan kita hamba yang senantiasa bersyukur kepadanya di kala lapang dan bersabar saat mendapatkan kesempitan. Terlebih di masa pandemi covid-19, dimana hampir semua orang mengalami dampak dari ganasnya virus tersebut, maka dibuthkan kesabaran dalam menghaadapi cobaan tersebut. Seperti halnya di Inggris, islam sebagai agama minoritas, maka dibutuhkan kesabaran untuk mengahadapi berbagai cobaan, baik dari segi fasilitas ibadah maupun secara Pendidikan (Wekke, I. S., \& Tang, A. (2016).

\section{Kesimpulan}

Sebagai manusia yang beriman, sabar dan syukur menjadi indicator untuk meraih surga. Seperti halnya cerita diatas bahwa ketika ditimpa musibah, maka sabar dan syukur adalah senjata yang paling utama. Sebagai contoh Nabi Ayyub AS yang diuji oleh Allah swt dengan berbagai macam ujian seperti ditimpa musibah penyakit yang berkepanjangan.

\section{Daftar Pustaka}

Fauzi, A. (2018). Moderasi Islam, Untuk Peradaban Dan Kemanusiaan. Jurnal Islam Nusantara, 2(2), 232-244.

Hajar S, I. (2014). Sistem Pengelolaan Bimbingan Manasik Haji-Umrah pada PT. Al-Bayan Permata Ujas (Doctoral dissertation, Universitas Islam Negeri Alauddin Makassar).

Indrawan, I. (2013). Model Pembelajaran Nabi Muhammad SAW; Hiwar, Analogi, Tashbih dan Amtsal. Jurnal al-Afkar, 1(2).

Mahmuda, M. (2018). ANAK YATIM SEBAGAI OBJEK DAKWAH DALAM PERSPEKTIF AL-QUR'AN. Al-Hikmah: Jurnal Dakwah dan Ilmu Komunikasi, 85-108.

Masyhuri, M. (2013). Ekonomi syariah dalam etika pemerataan resiko. Jurnal Ekonomi Dan Pembangunan, 21(2), 125-136.

Muhammad, K., Duski, S., \& Ilman, N. (2019).

Syawie, M. (2011). Kemiskinan dan kesenjangan sosial. Sosio Informa, 16(3).

Wekke, I. S., \& Tang, A. (2016). Kultur Pendidikan Islam Di Minoritas Muslim Inggris. THAQAFIYYAT: Jurnal Bahasa, Peradaban Dan Informasi Islam, 17(1), 70-83. 